\title{
Komunitas Laba-Laba (Arachnida: Araneae) Pada Lahan Perkebunan di Kawasan Taman Nasional Bogani Nani Wartabone Sulawesi Utara
}

\author{
Muh. Aswada*, Roni Koneria, Saroyoa, Parluhutan Siahaana \\ aJurusan Biologi, FMIPA, Unsrat, Manado
}

\begin{tabular}{l}
\hline K A T A K U N C I \\
\hline Kelimpahan \\
Laba-laba \\
Taman Nasional \\
Bogani Nani Wartabone
\end{tabular}

\begin{abstract}
A B S T R A K
Laba-laba dalam ekosistem berperan dalam mengendalikan populasi serangga dan dapat digunakan sebagai bioindikator yang baik untuk mendeteksi perubahan lingkungan. Penelitian ini bertujuan untuk mengkaji struktur komunitas laba-laba yang pada lahan perkebunan di kawasan Taman Nasional Bogani Nani Wartabone (TNBNW), Sulawesi Utara. Metode yang digunakan adalah perangkap jebak (Pitfall trap) dan jaring ayun (Sweep net). Tipe habitat yang dijadikan titik pengambilan sampel adalah perkebunan campuran, perkebunan jagung, dan semak. Hasil penelitian ini didapatkan sebanyak 442 individu laba-laba dari 59 spesies, 35 genera, dan 10 famili. Kekayaan dan keanekaragaman spesies laba-laba tertinggi terdapat di perkebunan campuran. Kelimpahan spesies tertinggi ditemukan di kebun jagung, sedangkan yang terendah di semak.
\end{abstract}

KE Y W OR D S

Abundance

Spider

National Park

Bogani Nani Wartabone

\section{A B S T R A C T}

In the ecosystem spiders had a role in controlling insects populations and can be used as a good bioindicator for detecting environmental changes. This study aims to examine the structure of spider community in the area of plantation in Bogani Nani Wartabone National Park, North Sulawesi. The method used is a pitfall traps and sweep net. Habitat types were used as the sampling point is a mixed plantation, corn field and shrubs. The results of this study found as many as 442 individual spiders of 59 species, 35 genera and 10 families. Richness and diversity of spider species was highest in a mixed plantation. The highest species richness was found in a corn field, while the lowest in the shrubs.

TERSEDIA ONLINE

25 Juli 2014

\section{Pendahuluan}

Laba-laba ditemukan hampir di seluruh permukaan bumi dari daerah kutub hingga daerah padang pasir yang kering. Laba-laba terutama berlimpah di tempat yang banyak vegetasi. Sampai saat ini sekitar 37.000 spesies laba-laba telah diberi nama, diyakini jumlah itu baru seperempat dari jumlah laba-laba yang ada di dunia (Suana, 2005).

Pengendalian hama di daerah pertanian di Kawasan TNBNW sampai saat ini masih menggunakan pestisida yang dampaknya akan berpengaruh buruk terhadap lingkungan serta organisme non target yang merupakan musuh alami dari serangga hama seperti laba-laba. Kartohardjono (2011) melaporkan bahwa aplikasi insektisida efektif mengendalikan hama secara parsial, tetapi secara bersamaan juga membunuh predator parasitoid yang sebenarnya berpotensi sebagai pengendali hama secara hayati.

Pemakaian pestisida dan herbisida yang berlebihan, dapat mempengaruhi kehadiran labalaba pada lahan perkebunan. Keberadaan laba-laba

*Corresponding author: Jurusan Biologi FMIPA UNSRAT, Jl. Kampus Unsrat, Manado, Indonesia 95115; Email address: muhaswad81@yahoo.co.id Published by FMIPA UNSRAT (2014) 
pada ekosistem perkebunan dapat membantu mengendalikan hama serangga secara alami, sehingga perlu dilakukan pengkajian keanekaragaman jenis-jenis laba-laba yang ada pada ekosistem pertanian di kawasan Taman Nasional Bogani Nani Wartabone sehingga dapat mengoptimalkan peran laba-laba di ekosistem pertanian.

Pemakaian pestisida dan herbisida yang berlebihan, dapat mempengaruhi kehadiran labalaba pada lahan perkebunan tersebut. Keberadaan laba-laba pada ekosistem perkebunan dapat membantu mengendalikan hama serangga secara alami, sehingga perlu dilakukan penelitian tentang komunitas laba-laba yang ada pada ekosistem perkebunan di Kawasan Taman Nasional Bogani Nani Wartabone sehingga dapat mengoptimalkan peran laba-laba di ekosistem pertanian. Penelitian ini bertujuan untuk mengkaji kelimpahan laba-laba pada lahan perekebunandi Kawasan Taman Nasional Bogani Nani Wartabone, Sulawesi Utara.

\section{Metode}

\subsection{Waktu dan Tempat Penelitian}

Penelitian ini dilaksanakan dari bulan Maret sampai April 2014, pada lahan perkebunan di Kawasan Taman Nasional Bogani Nani Wartbone, Bolaang Mongondow, Sulawesi Utara (Gambar 1).

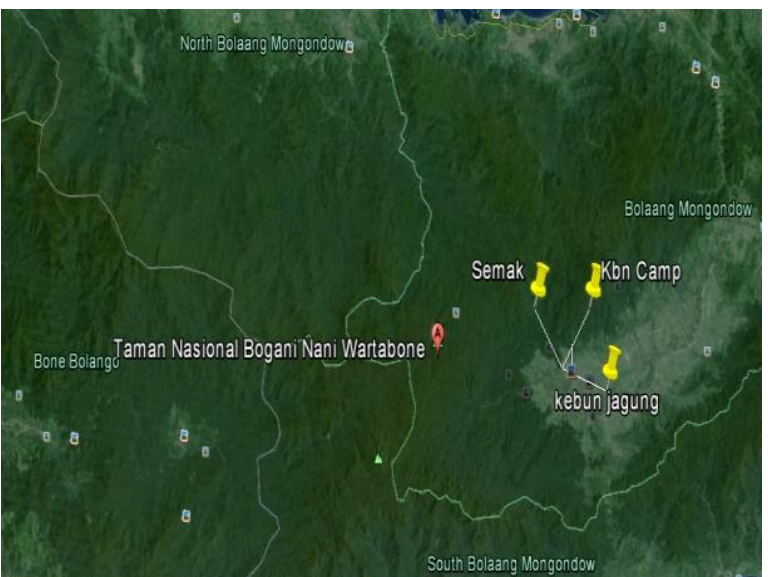

Gambar 1. Peta lokasi penelitian Taman Nasional Bogani Nani Wartabone (Google Earth, 2014).

\subsection{Material penelitian}

Alat-alat yang digunakan dalam penelitan ini adalah jaring ayun (sweep net), gelas plastik, GPS (Global Position System), kamera digital, mikroskop, linggis, buku identifikasi, perangkap jebak, tabung ependorf, plastik sampel, pensil dan buku tulis. Bahan-bahan yang digunakan yaitu alkohol 70\%, air, garam dan detergen.

\subsection{Teknik Pengambilan Sampel}

Penelitian ini menggunakan metode perangkap jebak (pitfall trap) yang digunakan untuk menangkap laba-laba yang bergerak aktif di permukaan tanah dan dengan menggunakan jaring ayun (sweep net) untuk menangkap laba-laba yang berada di vegetasi.

Setiap tipe habitat dibuat 4 transek dengan jarak masing-masing transek sekitar 6 meter, dan pada setiap transek ditanam 4 perangkap jebak dengan jarak masing-masing perangkap jebak sekitar 6 meter. Perangkap jebak digunakan untuk menangkap laba-laba yang bergerak aktif di permukaan tanah. Perangkap jebak terbuat dari gelas plastik air mineral volume $240 \mathrm{ml}$, diameter mulut gelas $7 \mathrm{~cm}$ dan tinggi $10 \mathrm{~cm}$. Larutan pengawet terdiri atas campuran air sebanyak 2 liter, detergen 50 gram dan garam 50 gram. Pada setiap perangkap jebak diisi larutan pengawet sebanyak $100 \mathrm{ml}$.

Pengambilan sampel dilakukan pada setiap tipe habitat dan setiap tipe habitat dibuat transek sebanyak 4 transek dengan jarak antar transek 50 m. Pengambilan sampel dengan menggunakan sweep net dilakukan dengan mengayunkan jaring sebanyak 100 kali ayunan pada setiap transek kemudian sampel yang tertangkap di masukkan ke dalam tabung Ependorf yang telah berisi alkohol untuk diawetkan.

Sampel laba-laba yang didapat dihitung jumlah individunya kemudian diidentifikasi berdasarkan ciri morfologi dengan menggunakan buku identifikasi Borror et al. (1996) dan buku hasil-hasil penelitian keanekaragaman laba-laba di Indonesia, seperti hasil penelitian dari Suana (2005), Rantung (2006), dan Tulung (1999).

\section{Hasil dan Pembahasan}

Hasil penelitian diperoleh sebanyak 442 individu laba-laba dari 59 spesies, 35 genera, dan 10 famili yang tertangkap dengan menggunakan perangkap jebak (Pitfall trap) dan jaring ayun (Sweep net). Perangkap jebak yang digunakan berhasil mengoleksi 3 famili yaitu, famili Sparassidae, Oxyopidae, dan Lycosidae. Menggunakan jaring ayun diperoleh sebanyak 8 famili yaitu, famili Araneidae, Clubionidae, Oxyopidae, Salticidae, Tetragnathidae, Uloboridae, Theridiidae, dan Thomisidae. Struktur komunitas laba-laba yang dibahas dalam penelitian ini meliputi kelimpahan, keanekaragman, kekayaan, dan kemerataan spesies.

Lokasi penelitian yang memiliki kelimpahan individu tertinggi yaitu pada perkebunan jagung dengan total individu yang tersampel sebanyak 180 individu (40,72\%). Perkebunan campuran memiliki kelimpahan individu terbanyak kedua dengan total individu yang tersempel sebanyak 171 individu (38,69\%), dan terendah pada semak dengan total individu yang tersampel sebaanyak 91 individu (20,59\%) (Tabel 1).

Rata-rata kelimpahan spesies laba-laba yang tertinggi ditemukan di perkebunan jagung yaitu sebanyak 45 individu, diikuti dengan kelimpahan individu di perkebunan campuran sebanyak 42,75 individu, dan terendah pada semak dengan 22,75 
individu (Gambar 2). Kelimpahan individu yang tertinggi pada perkebunan jagung ini disebabkan karena, tipe perkebunan tersebut merupakan tipe perkebunan monokultur yang dapat menyebabkan terjadinya ledakan atau meningkatnya populasi hama serangga tertentu sehingga keberadaan musuh alami hama serangga tersebut seperti laba- laba juga akan meningkat. Mulyani (2010) menyatakan bahwa, budidaya tanaman monokultur dapat mendorong suatu ekosistem pertanian rentan terhadap serangan hama serangga. Peningkatan keragaman tanaman dapat menekan perkembangan populasi hama serangga pada tanaman utama.

Tabel 1. Jumlah famili, genera, spesies dan individu laba-laba yang ditamukan pada lahan perkebunan campuran, perkebunan jagung dan semak.

\begin{tabular}{clcccccccccc}
\hline No. & Famili & Jml Genera & Jml Sp. & Kbn Camp & \% & Kbn jag & \% & Semak & \% & Grand Total & \% \\
\hline 1 & Araneidae & 7.00 & 10.00 & 43.00 & 9.73 & 33.00 & 7.47 & 12.00 & 2.71 & 88.00 & 19.91 \\
2 & Clubionidae & 1.00 & 3.00 & 1.00 & 0.23 & 1.00 & 0.23 & 1.00 & 0.23 & 3.00 & 0.68 \\
3 & Lycosidae & 1.00 & 1.00 & 17.00 & 3.85 & 9.00 & 2.04 & 1.00 & 0.23 & 27.00 & 6.11 \\
4 & Oxyopidae & 1.00 & 5.00 & 20.00 & 4.52 & 64.00 & 14.48 & 25.00 & 5.66 & 109.00 & 24.66 \\
5 & Salticidae & 10.00 & 13.00 & 15.00 & 3.39 & 5.00 & 1.13 & 8.00 & 1.81 & 28.00 & 6.33 \\
6 & Sparassidae & 1.00 & 1.00 & 0.00 & 0.00 & 1.00 & 0.23 & 0.00 & 0.00 & 1.00 & 0.23 \\
7 & Tetragnathidae & 2.00 & 6.00 & 43.00 & 9.73 & 38.00 & 8.60 & 25.00 & 5.66 & 106.00 & 23.98 \\
8 & Theridiidae & 5.00 & 6.00 & 2.00 & 0.45 & 3.00 & 0.68 & 8.00 & 1.81 & 13.00 & 2.94 \\
9 & Thomisidae & 6.00 & 13.00 & 30.00 & 6.79 & 26.00 & 5.88 & 10.00 & 2.26 & 66.00 & 14.93 \\
10 & Uloboridae & 1.00 & 1.00 & 0.00 & 0.00 & 0.00 & 0.00 & 1.00 & 0.23 & 1.00 & 0.23 \\
\hline
\end{tabular}
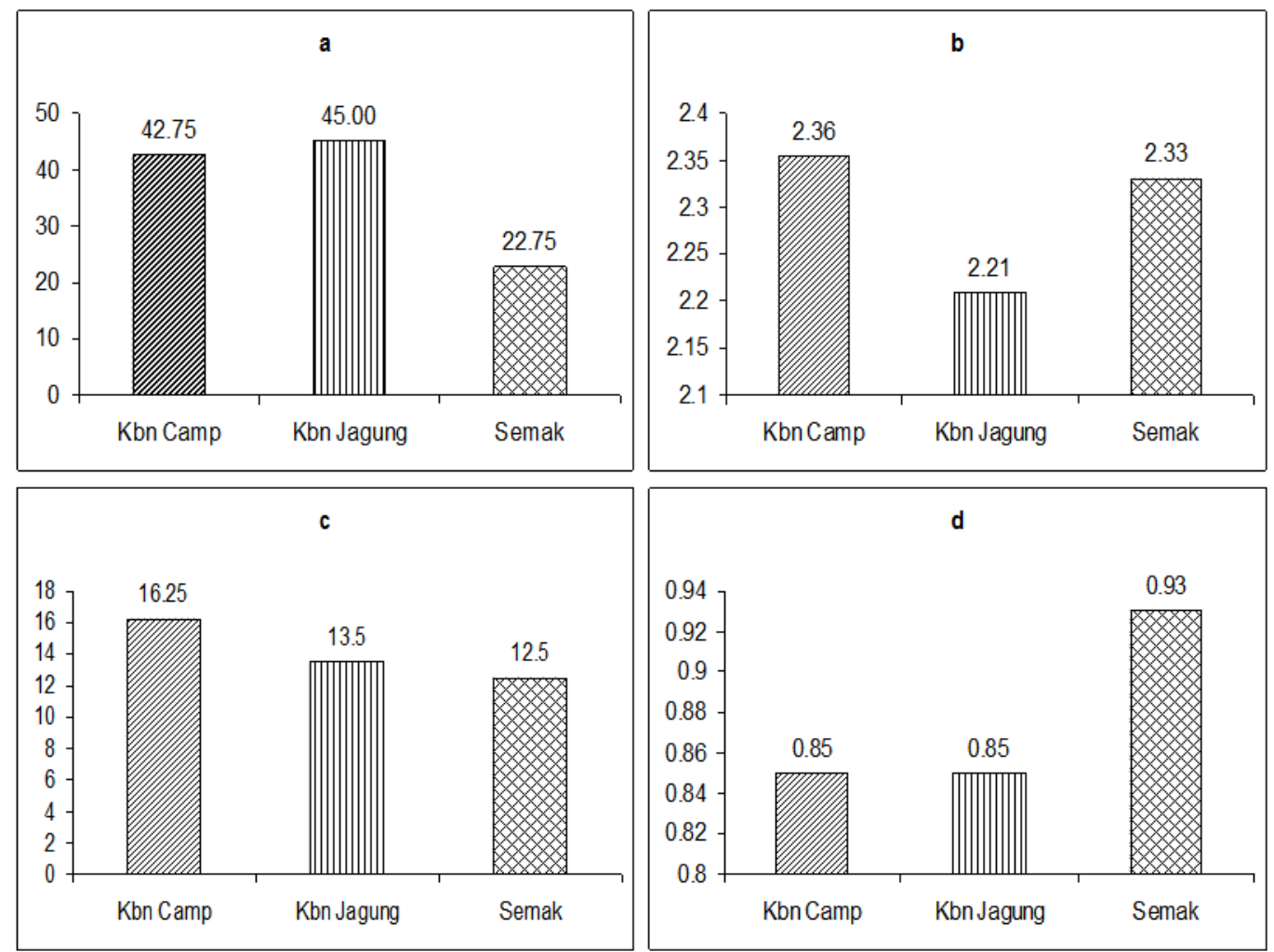

Gambar 2. Kelimpahan (a), Keanekaragaman (b), Kekayaan (c), dan Kemerataan (d) spesies laba-laba di perkebunan campuran, perkebunan jagung, dan semak.

Indeks keanekaragaman ( $\left.\mathrm{H}^{\prime}\right)$ laba-laba tertinggi ditemukan di daerah perkebunan campuran dengan nilai 2,36, kemudian pada semak dengan nilai 2,33 dan terendah pada daerah perkebunan jagung dengan nilai 2,21 (Gambar 2). Tingginya nilai keanekaragaman di perkebunan campuran ini disebabkan karena beragamnya vegetasi yang ada di lokasi tersebut. Suana (2005) dan Kamal et al. (2011) menyatakan bahwa, keanekaragaman spesies umumnya akan meningkat sejalan dengan meningkatnya keragaman struktur habitat.

Kekayaan spesies laba-laba tertinggi didapatkan di perkebunan campuran dengan 16,25 spesies, kemudian di daerah perkebunan jagung dengan nilai 13,5 dan semak dengan nilai 12,5 
(Gambar 2). Tingginya kekayaan spesies di perkebunan campuran ini, juga disebabkan karena beranekaragamnya vegetasi yang ada pada lokasi tersebut. Suana (2005) menyatakan bahwa, struktur bentang alam yang kompleks akan menyediakan beragamnya tipe habitat sehingga menyebabkan semakin banyak laba-laba yang dapat berkoeksistensi di dalamnya.

Kemerataan spesies laba-laba tertinggi yang didapatkan dalam penelitian ini yaitu pada loaksi semak dengan nilai 0,93 dan diikiuti oleh nilai kemerataan spesies di perkebunan campuran dan perkebunan jagung dengan nilai masing-masing 0,85 (Gambar 2). Rendahnya nilai kemerataan spesies pada perkebunan campuran dan jagung ini disebabkan karena, pada lokasi tersebut terdapat beberapa spesies yang dominan, sedangkan kabanyakan spesies yang tersampel lainnya memiliki jumlah yang sedikit. Suana (2005) menyatakan bahwa, nilai kemerataan spesies akan cenderung semakin rendah apabila dalam sampel terdapat satu atau beberapa spesies yang dominan sedangkan kebanyakan spesies yang lainnya memiliki jumlah yang sedikit. Spesies laba-laba yang mendominasi di pertanian campuran yaitu Eriophora sp 1 dan Leucage decorata, sedangkan spesies yang mendominasi pada pertanian jagung yaitu Oxyopes quadrifasciatus dan Leucage decorata.

\section{Kesimpulan}

Kelimpahan spesies laba-laba tertinggi terdapat di perkebunan campuran dan yang terendah di semak. Indeks keanekaragaman laba-laba tertinggi didapatkan di perkebunan campuran dan terendah di perkebunan jagung. Kekayaan spesies tertinggi didapatkan di perkebunan campuran dan yang terendah di semak. Rata-rata kemerataan spesies tertinggi didapatkan di semak dan yang terendah di perkebunan campuran dan perkebunan jagung.

\section{Daftar Pustaka}

Borror, D. J., C. A. Triplehorn, N. F. Johnson. 1996. Pengenalan Pelajaran Serangga Edisi Keenam. Gadjah Mada University Press. Yogyakarta.

Kamal, M., I. Yustian., S. Rahayu. 2011. Keanekaragaman Jenis Arthropoda di Gua Putrid an Gua Selabe Kawasan Karts Padang Bindu, OKU Sumatera Sealatan. Jurnal Penelitian Sains. 14(1): 34-35.

Kartohardjono, A. 2011. Penggunaan Musuh Alami Sebagai Komponen Pengendalian Hama Padi Berbasis Ekologi. Pengembangan Inovasi Pertanian. 4(1): 36.

Mulyani, L. 2010. Implementasi Sistem Pertanaman Kubis: Kajian Terhadap Keragaman Hama dan Musuh Alami. [Skripsi]. Universitas Sebelas Maret. Jakarta.

Rantung, J. CH. S. 2006. Keragaman Spesies LabaLaba Di Seksi Konservasi Wilayah II Taman Nasional Bogani Nani Wartabone, Doloduo, Bolaang Mongondow. [Skripsi]. Universitas Sam Ratulangi. Manado.

Smith, G., T. Gitting, M. Wilson, L. French, A. Oxbrough, S. O'Donoghue. J. Pithon, V. O'Donnell, A.-M. McKee, S. Iremonger, J. O'Halloran, D. Kelly, F. Mitchell, P. Giller, T. Kelly. 2005. Assessment of Biodiversity at Different Stages of the Forest Cycle. University College Cork.

Suana, I. W. 2005. Bioekologi Laba-laba pada Bentang Alam Pertanian di Cianjur: Kasus Daerah Aliran Sungai (DAS) Cianjur, Sub-sub DAS Citarum, Kabupaten Cianjur, Jawa Barat. [Disertasi]. Sekolah Pascasarjana Institut Pertanian Bogor. Bogor.

Tulung, M. 1999. Ekologi Laba-laba di Pertanaman Padi dengan Perhatian Utama pada Pardosa pseudoannulata (Boes. \& Str.). [Disertasi]. Program Pascasarjana Institut Pertanian Bogor. Bogor. 